\title{
Landfalling tropical cyclones on the Pacific coast of Mexico: 1850-2010
}

\author{
G. B. RAGA \\ Centro de Ciencias de la Atmósfera, Universidad Nacional Autónoma de México, Ciudad Universitaria, \\ 04510 México, D.F. \\ Corresponding author: G. B. Raga; e-mail: graciela.raga@gmail.com \\ B. BRACAMONTES-CEBALLOS \\ Facultad de Ciencias Politicas y Sociales, Universidad de Colima, Campus Norte, Km. 3.2 Carretera \\ Colima-Guadalajara, 28010 Colima, México \\ L. M. FARFÁN \\ Centro de Investigación Cientifica y de Educación Superior de Ensenada,Unidad La Paz, Miraflores 334, \\ La Paz 23050, Baja California Sur, México \\ R. ROMERO-CENTENO \\ Centro de Ciencias de la Atmósfera, Universidad Nacional Autónoma de México, Ciudad Universitaria, \\ 04510 México, D.F.
}

Received December 1, 2011; accepted October 16, 2012

\begin{abstract}
RESUMEN
Se revisaron periódicos y documentos históricos de los estados del Pacífico mexicano ubicados al norte de $14^{\circ} \mathrm{N}$, para determinar la frecuencia de eventos de entrada a tierra de ciclones tropicales desde 1850 hasta 1949, cuando comienza la base de datos del Centro Nacional de Huracanes de Estados Unidos. Los documentos consultados únicamente existen en repositorios nacionales, estatales y municipales, y la búsqueda sistemática realizada en este estudio ha aportado información valiosa que no puede hallarse en otro lugar. A partir de estos documentos se ha reconstruido una base de datos que se remonta a 1850, la cual indica que ha habido tanto periodos activos como de poca incidencia de eventos de entrada a tierra. En promedio se observan $1.8 \pm 1.6$ eventos de este tipo por año, considerando el periodo 1850-2010. Cuando la serie se limita al periodo 1880-2010, sin considerar los primeros 30 años, en los que podría haber una subestimación de casos de entrada a tierra, el valor promedio aumenta a $2.1 \pm 1.6$ por año. El análisis espectral y de ondeletas de la serie completa de 161 años indica que la entrada a tierra por el Pacífico mexicano está modulada por la Oscilación Decenal del Pacífico. La influencia de El Niño/Oscilación del Sur y de la Oscilación del Atlántico Norte parece estar presente en la serie reconstruida pero la correlación es menor que con la Oscilación Decenal del Pacífico.
\end{abstract}

\section{ABSTRACT}

Historical documents and newspapers from Mexican Pacific states (north of $14^{\circ} \mathrm{N}$ ) were reviewed to determine the incidence of landfalling tropical cyclones from 1850 to 1949, prior to the start of the United States National Hurricane Center database. The reviewed documents are only found in Mexican repositories at national, state and municipal level and the systematic search embarked upon in this study yielded valuable information that cannot be found elsewhere. A time series of landfall was reconstructed back to 1850, indicating active and quiet periods. 
An average of $1.8 \pm 1.6$ landfalls per year is determined from the time series for $1850-2010$. When the series is limited to 1880-2010, eliminating the first 30 years that may have some undercounting, the average increases to $2.1 \pm 1.6$ cases per year. Spectral and wavelet analysis of the 161 years of landfalling tropical cyclones indicates that the Pacific Decadal Oscillation (PDO) modulates the activity. The influence of El Niño/Southern Oscillation (ENSO) and the North Atlantic Oscillation (NAO) on the landfall frequency may be present throughout the reconstruction period but both oscillations have lower correlations compared to that from the PDO.

Keywords: Tropical cyclones, landfalling, Pacific coast of Mexico.

\section{Introduction}

The last two decades, since the studies reported in Bradley and Jones (1992) were published, have experienced a large increase in the number of publications that make use of different variables as well as historical documents as proxies to retrieve information about the past climate. García et al. (2001) and García-Herrera et al. (2003) reconstructed atmospheric circulation changes in the Tropical Pacific from the voyages of the Spanish galleons from 1590 to 1750 . They were able to infer that the sailing time between modern Mexico and the Philippines was a function of the strength of the trade winds and the location of the western Pacific monsoon trough. They concluded that the atmospheric circulation of the western Pacific underwent a large decadal fluctuation during the 18 th century.

The compilation by García-Acosta et al. (2003) provides a unique catalogue of climaticallyinduced agricultural disasters from pre-hispanic times (958 AD) to the first half of the 20th century, making use of codex and colonial documents in the Mesoamerican region. They identified several cases of landfalling tropical cyclones (TCs) in the Mayan region (starting in 1462) as well as a few events that affected the Pacific in 1530 (Sinaloa), in 1573 (Colima) and in 1586 (Nayarit). Only two events were reported in the 1600s in Guerrero and Chiapas (both located in the southern coast of Mexico), while five landfalling events were reported in the same region during the 18th century. A systematic study is currently underway to determine the full extent of landfalling cyclones in the aforementioned region as well as in the Yucatán peninsula and the Gulf of Mexico coast (García-Acosta and Padilla-Lozoya, personal communication). The TC that in 1959 caused the destruction of about $75 \%$ of the town and hundreds of deaths in Minatitlán (Colima) has been extensively documented by Padilla-Lozoya (2007). Late in the 2011 season, the same area was affected by the landfall of TC Jova.

Serra (1971) presented a first reconstruction of eastern Pacific TC trajectories between 1921 and 1969 , calculating a probability of $90 \%$ or greater that at least one TC per year would affect one of five of the 10 Mexican states. However, the study does not clearly indicate how the trajectories were estimated, presumably based upon ship reports located far from the coastline. Moreover, Serra (1971) estimated that the landfall probabilities in the Baja California peninsula and the state of Sinaloa were approximately 50 and 40\%, respectively. Englehart et al. (2008) have analyzed the period 1921-2005 and conclude that there is non-random behavior in the number of near-shore TCs and point towards long-term variability.

Romero-Vadillo et al. (2007) present a general climatology of TCs in the eastern North Pacific and also discuss the El Niño/Southern Oscillation (ENSO) influence on the observed variability. Jáuregui (2003) provides a spatial distribution of landfalling cyclones updated to 2000, highlighting the large number that affect the southern tip of the Baja California peninsula. The influence of 
topography on the trajectories was explored by Zavala-Sansón (2004), suggesting that trajectories tend to be "trapped" near the coast, which would lead to more frequent landfalls in the southern peninsula and this is consistent with the available observations.

More recently, Camargo et al. (2008) identified through cluster analysis three distinct types of trajectories and determined that only $15 \%$ made landfall, when considering all the TC trajectories in the records of the United States National Hurricane Center (NHC). However, they identified that only one cluster had a 35\% landfall frequency (independent of ENSO phase). Tropical cyclones that have trajectories in such cluster appear to originate further south and closer to the coast of Mexico than TCs in the other clusters.

Tropical cyclones that develop in the eastern North Pacific basin and make landfall in Mexico play a significant role on the availability of water in the arid and semi-arid regions of the northwest (NW). Moreover, TC activity in this basin influences the summer monsoon in the region. Englehart and Douglas (2001) analyzed the precipitation in 18 stations, from Oaxaca to Baja California Sur (BCS) and determined the rainfall contribution associated with TCs to the total rainfall. They concluded that the TC contribution was more spatially coherent than the non-TC contribution. More recently, Larson et al. (2005) extended the Englehart and Douglas (2001) results by using a gridded precipitation dataset for the period 1950-1998 to estimate the TC influence over the whole country, identifying the variability in terms of spatial and monthly distributions. Between 80 and $90 \%$ of the October precipitation in NW Mexico is associated with TCs.

The limited coverage of the available NHC dataset for the eastern Pacific, from 1949 to the present, extended back to 1921 by Serra (1971), prevents the analysis of the longer term variability of landfalling TCs. The objective of this study is to extend the time series of landfalling TCs onto western Mexico, back to 1850 and evaluate its variability. Our study is similar to that carried out by Fernández-Partagás and Diaz (1996) for the Atlantic basin, but limited only to landfalling events.

\section{Historical records}

The time series reconstruction of landfalling TCs onto the Pacific coast of Mexico was determined from a variety of sources. The national library of Mexico (Biblioteca Nacional) and the national newspaper archive (Hemeroteca Nacional) constitute the national repositories since 1867 and 1921, respectively. A search was conducted for documents related to loss of life and property damage in the Pacific states associated with heavy rains and winds for the period 1850-1949 (Table I). In this first stage of the survey, the decision was made to limit the study period to the 100 years prior to the start of the NHC database for the Eastern Pacific. Even though there are questions about the validity of the total number of cyclones in the database before the satellite era, we consider that this is adequate if the focus is only on the landfalling TCs. The search at the national repositories provided the startup documentation that was then supplemented by visits to local libraries in major Mexican cities (Acapulco, Chilpancingo, Guadalajara, Colima, Mazatlán, Culiacán and La Paz). Documents found in those cities were mostly official government reports requesting financial aid to the central government to cope with the losses associated with meteorological phenomena. Photographs from the early 20 th century were also found, that documented floods as well as general damage to infrastructure (such as piers, roads, etc.) and to private property. The local repositories also had local and regional newspapers (as shown in Fig. 1) that provided a 
Table I. Sample excerpts from different types of documents consulted for this study.

\begin{tabular}{|c|c|c|c|}
\hline Date/state & Transcript of text describing the event & Reference & Repository \\
\hline $1857 / 09 / 30-10 / 01$ Historical document & $\begin{array}{l}\text { The hurricane started the evening of } 30 \\
\text { September in La Paz. }\end{array}$ & $\begin{array}{l}\text { AHPLM 2206, 2207, 2209, 2210, } \\
2212,2213,2214,2215 .\end{array}$ & $\begin{array}{l}\text { Archivo Histórico } \\
\text { Pablo L. Martínez }\end{array}$ \\
\hline
\end{tabular}

California Sur

\begin{tabular}{lll}
\hline 1884/10/13 & Regional & At 10:00 am on 13 October 1884 another \\
newspaper: & cyclone from the south moved almost \\
Michoacán & Ecos de la Costa & $\begin{array}{l}\text { American ship Granada that was caught } \\
\text { Ame our coasts sinking the } \\
\end{array}$ \\
& by the winds off-shore of the limit \\
& between Michoacán and Colima, and \\
& luckily its force was not felt on shore.
\end{tabular}
F. Hernández Espinosa: "Los meses Archivo Histórico de octubre a través del tiempo en y Hemeroteca de nuestras costas", cited in Ecos de la la Universidad de Costa, pp. 8-9 (9 Jan 1960).
Colima

\begin{tabular}{llll}
\hline 1895/09/30 & $\begin{array}{l}\text { Thesis, based } \\
\text { on original newspaper } \\
\text { report }\end{array}$ & $\begin{array}{l}\text { At El Triunfo (located in Baja California } \\
\text { Sur) the storm lasted from the 30th till the } \\
\text { 2nd with extraordinary violence. }\end{array}$ & $\begin{array}{l}\text { E. Villanueva González: "Presencia Biblioteca Ángel } \\
\text { de huracanes en Baja California Sur, Palerm, CIESAS, } \\
\text { el caso del ciclón Liza", pp. 61-62. México D.F. }\end{array}$ \\
$\begin{array}{l}\text { Baja } \\
\text { California Sur }\end{array}$ & & $\begin{array}{l}\text { "El Temporal, en la Baja California", Archivo Histórico } \\
\text { in El Correo de la Tarde } \\
\text { (12 Oct 1895). }\end{array}$ & $\begin{array}{l}\text { Municipal de } \\
\text { Mazatlán, Sinaloa }\end{array}$
\end{tabular}

\begin{tabular}{|c|c|c|c|c|}
\hline $\begin{array}{l}1902 / 09 / 24, \\
25,26 \\
\text { Guerrero }\end{array}$ & $\begin{array}{l}\text { Government } \\
\text { report }\end{array}$ & $\begin{array}{l}\text { The hurricane affected Chilpancingo, } \\
\text { Chilapa, Tlapa, Ometepec, Acapulco, } \\
\text { Huamuxtitlán, Montes de Oca, Tabares, } \\
\text { Ayutla and Abasolo. }\end{array}$ & $\begin{array}{l}\text { Periódico Oficial del Gobierno del } \\
\text { estado de Guerrero } \\
\text { (26 Sep. 1902) }\end{array}$ & $\begin{array}{l}\text { Hemeroteca Nacional } \\
\text { Digital de México, } \\
\text { UNAM }\end{array}$ \\
\hline $\begin{array}{l}\text { 1930/10/15 } \\
\text { Michoacán }\end{array}$ & $\begin{array}{l}\text { Chronology by the } \\
\text { Secretaría de Recursos } \\
\text { Hidráulicos (Ministry } \\
\text { of Hydraulic } \\
\text { Resources) }\end{array}$ & $\begin{array}{l}\text { A cyclone affected directly the central } \\
\text { Pacific coast between } 15 \text { and } 21 \text { October } \\
1930 .\end{array}$ & $\begin{array}{l}\text { Secretaría de Recursos Hidráulicos, } \\
\text { Dirección de Hidrología (1961): } \\
\text { "Fechas en que ocurrieron los } \\
\text { ciclones que se estima afectaron } \\
\text { directamente la zona Pacífico- } \\
\text { Centro", in Boletín Hidrológico 16, } \\
503 \text { (data from the central Pacific } \\
\text { region). }\end{array}$ & $\begin{array}{l}\text { Archivo de la } \\
\text { Comisión Nacional } \\
\text { del Agua }\end{array}$ \\
\hline $\begin{array}{l}\text { 1932/08/29 } \\
\text { Michoacán }\end{array}$ & History book & $\begin{array}{l}\text { A cyclone affected directly the coast up } \\
\text { to the highlands of the Sierra Madre del } \\
\text { Sur: Arteaga, Aguililla, Coalcomán, } \\
\text { Aquila and Villa. }\end{array}$ & $\begin{array}{l}\text { J. Oseguera Velásquez (1989). } \\
\text { Efemérides de Colima y de México } \\
\text { 1325- 1989. Guadalajara: Impre-Jal, } \\
128 \text { pp. }\end{array}$ & $\begin{array}{l}\text { Archivo Histórico del } \\
\text { Municipio de Colima }\end{array}$ \\
\hline
\end{tabular}

wealth of information, which has been catalogued for further research. Over one thousand records were created in association with the information retrieved, and were filed as cards specifically designed for this project (an example is shown in Fig. 2). The records were divided into months, and in this study we only focus on the evidence of landing tropical systems, considering events from May through November. Most of the Pacific coast was considered, encompassing the states of Guerrero, Jalisco, Sinaloa and BCS. The state of Sonora was not investigated, since in 

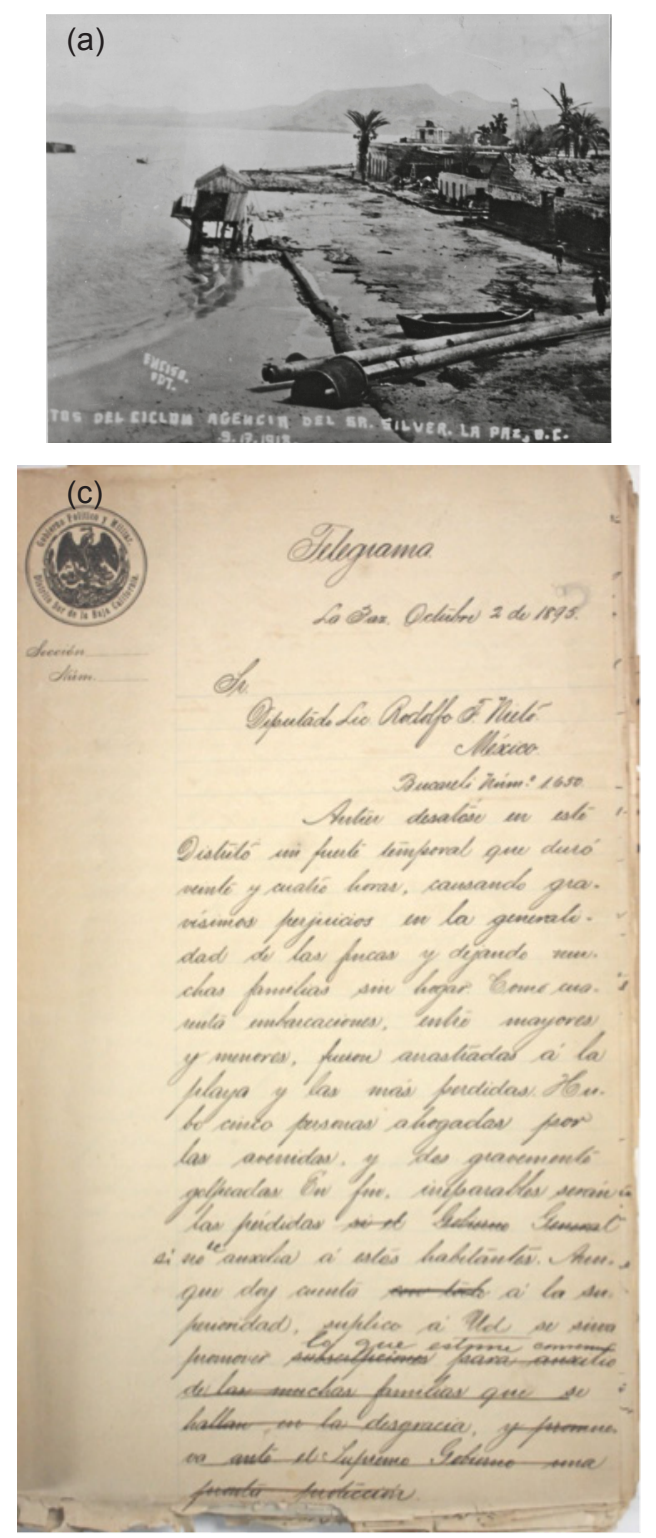

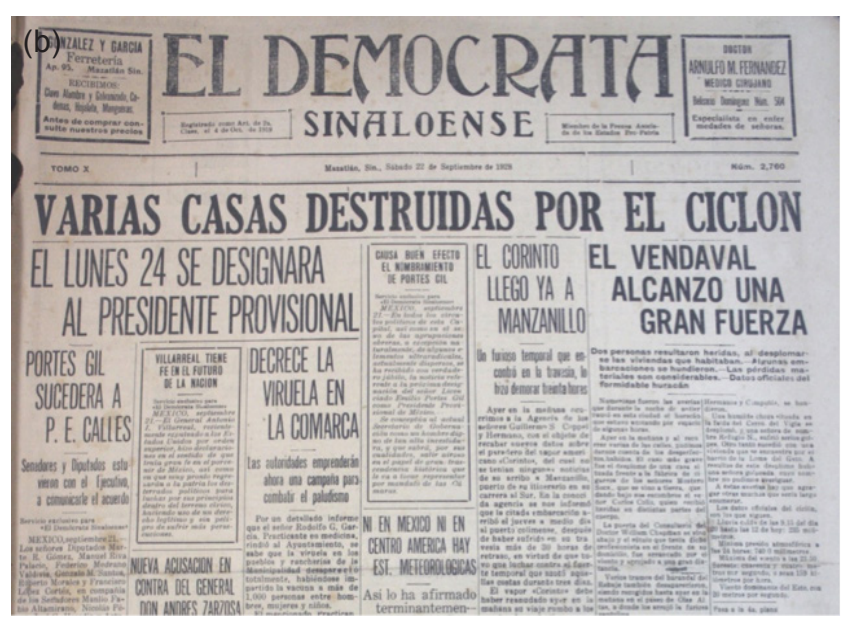

Fig. 1. Examples of the data sources out of which the information from landfalling cyclones was extracted. (a) Photograph taken in La Paz, B.C.S., 17 September 1918; (b) Front page of the newspaper El Democrata Sinaloense from Mazatlán, on 22 September 1928, reporting damage from the cyclone that started affecting the city two days earlier; and (c) handwritten message from the local government in La Paz sent to the representative in the central legislature on 2 October 1895 describing the damage caused by the cyclone that affected the city during 24 hours, including five deaths by drowning and two seriously injured.

the modern era, most of the cyclones that have affected this state had first moved across BCS. We also left out Chiapas and Oaxaca where very few cases have entered in the modern era and because they are included in another study currently under way to document TC landfalls from early colonial times and to investigate the social responses and population adaptation under the natural threats associated with TCs (García-Acosta and Padilla-Lozoya, personal communication).

\section{Results}

The total number of TCs that made landfall in each of the four states analyzed from 1850 to 1949 , binned in two-year periods, is presented in Figure 3. Early in the period, from 1850 to 1863, there 


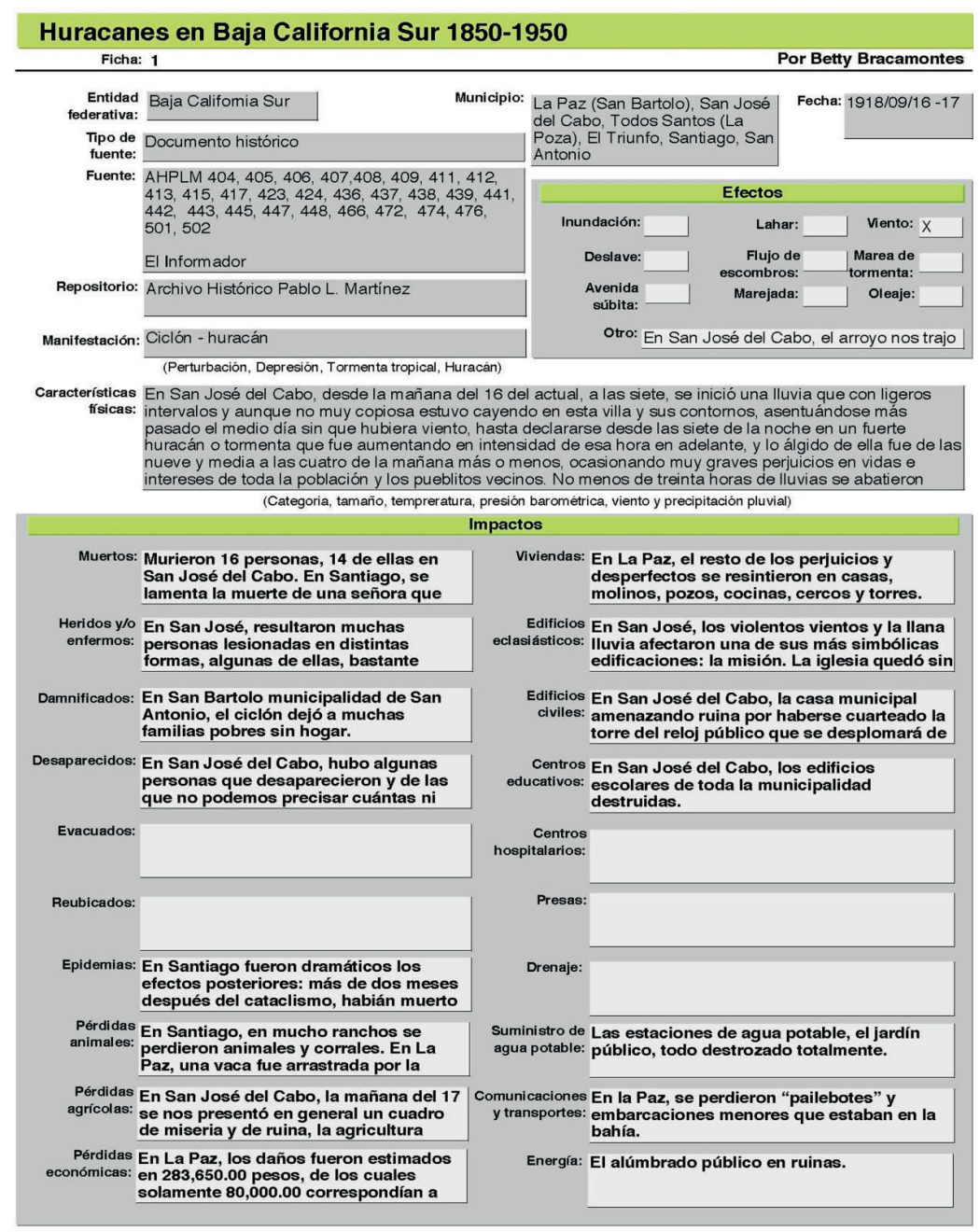

Fig. 2. Example of the cards designed with to transcribe the information for the different historical and newspaper sources. There are entries for location (state, municipality/county, city) and date, as well as: type of phenomenon, effects (high wind, swell, waves, floods), number of deaths, number of displaced, estimates of agricultural losses, estimates of economic losses, affected infrastructure (government buildings, schools, hospitals, roads, dams, sewage and energy).

are a number of reports from the state of BCS. but very few in the other three states. Even though there were plenty of documents available, almost no cyclones were reported affecting Sinaloa, Jalisco and Guerrero in those 14 years. In contrast, a maximum of four landfalls is reported in the biennium 1854-1855 in BCS. This relatively high activity is followed by 16 years (1864-1879) of very low activity, as reported in the documents found in the historical archives. A large increase in reports in all four states is seen after 1880, particularly in the Baja California Peninsula where four cyclones made landfall in the period 1882-1883. Up to 1911 there are numerous reports in all four states and then again there is a decrease to very few reports from 1912 to 1916. A large 
Landfalling tropical cyclones

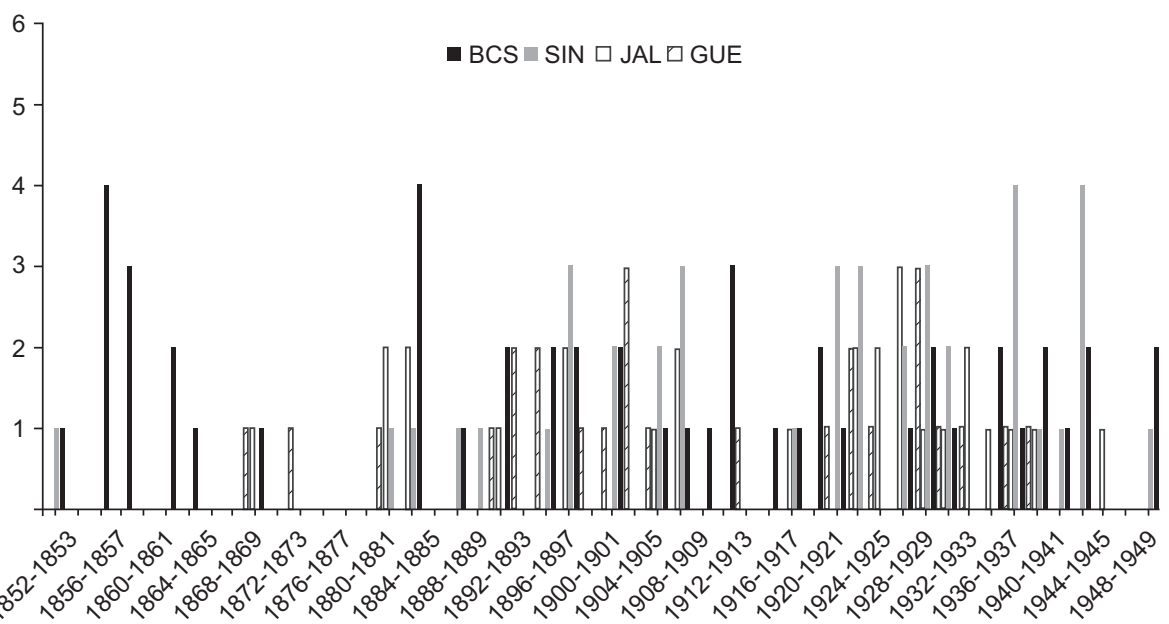

Fig. 3. Total number of landfalling tropical cyclones (binned every two years) from 1850 to 1949 , for the states of Baja California Sur (BCS), Sinaloa (SIN), Jalisco (JAL) and Guerrero (GUE).

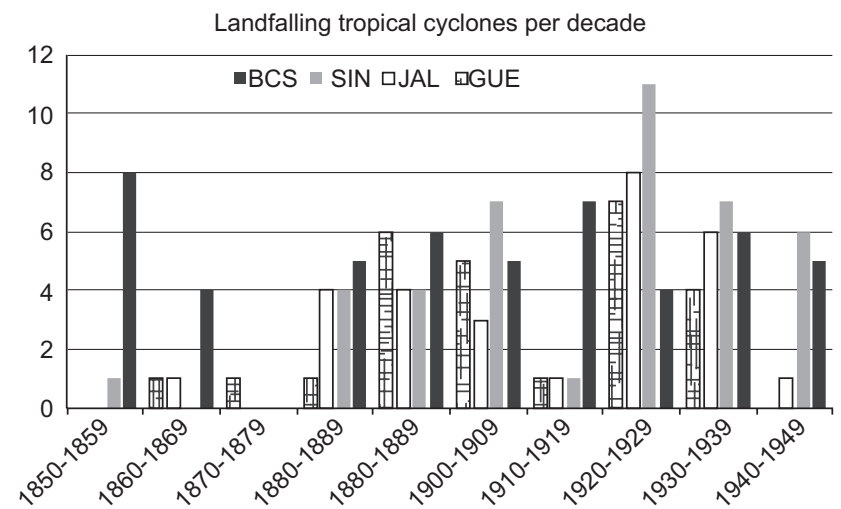

Fig. 4. Total number of landfalling tropical cyclones per decade from 1850 to 1949, for the states of Baja California Sur (BCS), Sinaloa (SIN), Jalisco (JAL) and Guerrero (GUE).

increase in the number of reports is observed in the following 12 years, and then again a relative minimum from 1932 to 1935, a pattern that repeats itself a couple more times up to the end of the reconstructed series in 1949.

The decadal variability as a function of the state where landfall occurred is shown in Figure 4. The decade with the highest number of landfalls is 1920-1929, with a total of 30 TCs. In contrast, the decade from 1870 to 1879 constitutes the minimum of the whole period, with only one landfall in the state of Guerrero (the southernmost of the four states considered here) and no landfalls in the northwest, where typically most of the landfalls occur in the official NHC dataset (e.g., Blake et al., 2009). The largest number of TCs that made landfall in the southern half of the Baja California peninsula (BCS) in a single decade (eight) occurred between 1850 and 1859, at the beginning of 
Table II. Basic statistics of the reconstructed time series of landfalling tropical cyclones for the period $1850-2010$.

\begin{tabular}{lcc}
\hline Parameter & Value & $95 \% \mathrm{CI}$ \\
\hline $\mathrm{N}$ & 161 & \\
Mean & 1.8 & $(1.6,2.1)$ \\
$\mathrm{SD}$ & 1.6 & $(1.4,1.7)$ \\
\hline
\end{tabular}

the reconstructed series.

The historical series was combined with the official NHC record up to 2010 to generate a reconstructed time series of 161 years in length and to evaluate basic statistics and variability. A total of 295 TCs made landfall for the abovementioned states in the period 1850-2010, but no cyclones made landfall during 38 of the 161 years. Table II presents the basic statistics of the time series, with

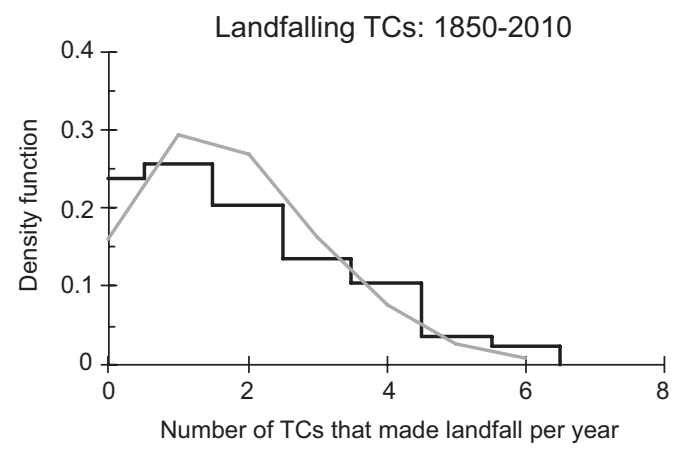

Fig. 5. Distribution of the total number of tropical cyclones that made landfall between 1850 and 2010 onto the Pacific Mexican states of Guerrero, Jalisco, Sinaloa and BCS. The grey curve corresponds to the Poisson fit.

a mean of 1.8 landfalls per year and a standard deviation of 1.6. The 95\% confidence interval for the mean is $(1.6,2.1)$. No landfall was observed in $38(23.6 \%)$ out of the 161 years analyzed, while years in which four or more TCs made landfall have occurred in $16.8 \%$ of the analyzed period. The probability density function is shown in Figure 5 as a histogram (black line). The gray curve corresponds to the values of a Poisson distribution with a lambda parameter of 1.8, corresponding to the mean of the distribution. This Poisson fit allows us to estimate that there is a $26.8 \%$ probability that two landfalls would occur in any given year, while the probability of five landfalls is only $2.7 \%$.

A basic spectral analysis of the time series results in the periodogram shown in Figure $6 a$, with a significant peak at about 40 years. Providing complementary information, the wavelet analysis (Fig. 6b) indicates that throughout the whole time series there is power associated with phenomena that exhibit a 2-5 year period. But most strikingly, there is a large peak in power for periods between 30 and 50 years that started developing towards the beginning of the 20th century.

In order to explore the nature of this variability, we consider the natural modes of the coupled atmosphere-ocean system: El Niño/Southern Oscillation (ENSO) and the North Atlantic Oscillation (NAO), which are responsible for inter-annual variability and may influence the landfalling events. ENSO is known to significantly affect the frequency and trajectories of TCs in the Atlantic basin, but has only a minor role in the frequency at the eastern Pacific basin (Romero-Vadillo et al., 
Table III. Spearman correlation coefficient between the reconstructed annual time series of landfalling tropical cyclones and climate indices related to wellestablished patterns. The indices were provided by the Climate Prediction Center of the National Oceanic and Atmospheric Administration.

\begin{tabular}{clc}
\hline Period & Index & Correlation \\
\hline $1850-2010$ & NAO & $0.22^{*}$ \\
$1866-2009$ & SOI & $0.13^{* *}$ \\
$1900-2010$ & PDO & $0.31^{*}$ \\
$1856-2010$ & Niño3 & $0.22^{*}$ \\
\hline
\end{tabular}

*Value significant at the $99 \%$ level.

$* *$ Value significant at the $90 \%$ level.

NAO: North Atlantic Oscillation; SOI: Southern

Oscillation Index; PDO: Pacific Decadal Oscillation

2007), and only significantly affects the frequency of occurrence of category 4 and 5 hurricanes. The phases of the NAO are related to the strength and position of the Azores-Bermuda anticyclone, and may be related to the flow responsible for steering eastern Pacific TCs onshore. We also wish to consider the Pacific Decadal Oscillation (PDO) as a possible influence in modulating landfalls in the decadal timescale.

The Spearman rank correlation coefficients between the reconstructed time series for landfall and several annually averaged climate indices are presented in Table III. Note that both ENSO, as characterized by the Niño3 index, and the NAO show the same correlation (0.22), significant at the $99 \%$ level evaluated using a $t$-test with $n$ - 2 degrees of freedom. This low correlation is evident in somewhat elevated power in the wavelet analysis (see Fig. 6b). We have separated the time series into two subsets: (i) cases of landfall events when the Niño3 index is larger than 0.5 (73 cases) and (ii) cases of landfall events when the index is less than -0.5 (49 cases). There is no significant difference in the average of landfalls between these two subsets. Moreover, $57 \%$ of the landfalls occur during neutral years when the Niño3 index has values between -0.5 and 0.5 , but the average landfalls per year are not significantly different than during either El Niño or La Niña conditions. Therefore, it appears that the ENSO phenomenon does not significantly influence the average cases of landfall of TCs that originate in the eastern North Pacific basin.

The largest correlation of the landfalling time series is with the PDO index $(0.31$, significant at the $99 \%$ level). The PDO pattern has been shown to also correlate with other observations in the region. Englehart and Douglas (2001) explored the relationship of rainfall variability in western Mexico with the equatorial rainfall index (ERI) and an index for the PDO and determined that the first mode of variability of the TC rainfall is significantly (95\%) related to the PDO. Brito-Castillo et al. (2002) also observed that the fill capacity of dams, related to the precipitation over land, was correlated with the PDO. The results of those previous studies are based upon modern records of observations from 1921 to 1999 (Brito-Castillo et al., 2002) and the period 1927-1997 (Englehart and Douglas, 2002). The reconstructed time series presented in our study extending back in time for several decades, to 1850 , indicates that landfalling TCs from Guerrero to BCS appear to be primarily modulated by the PDO. 

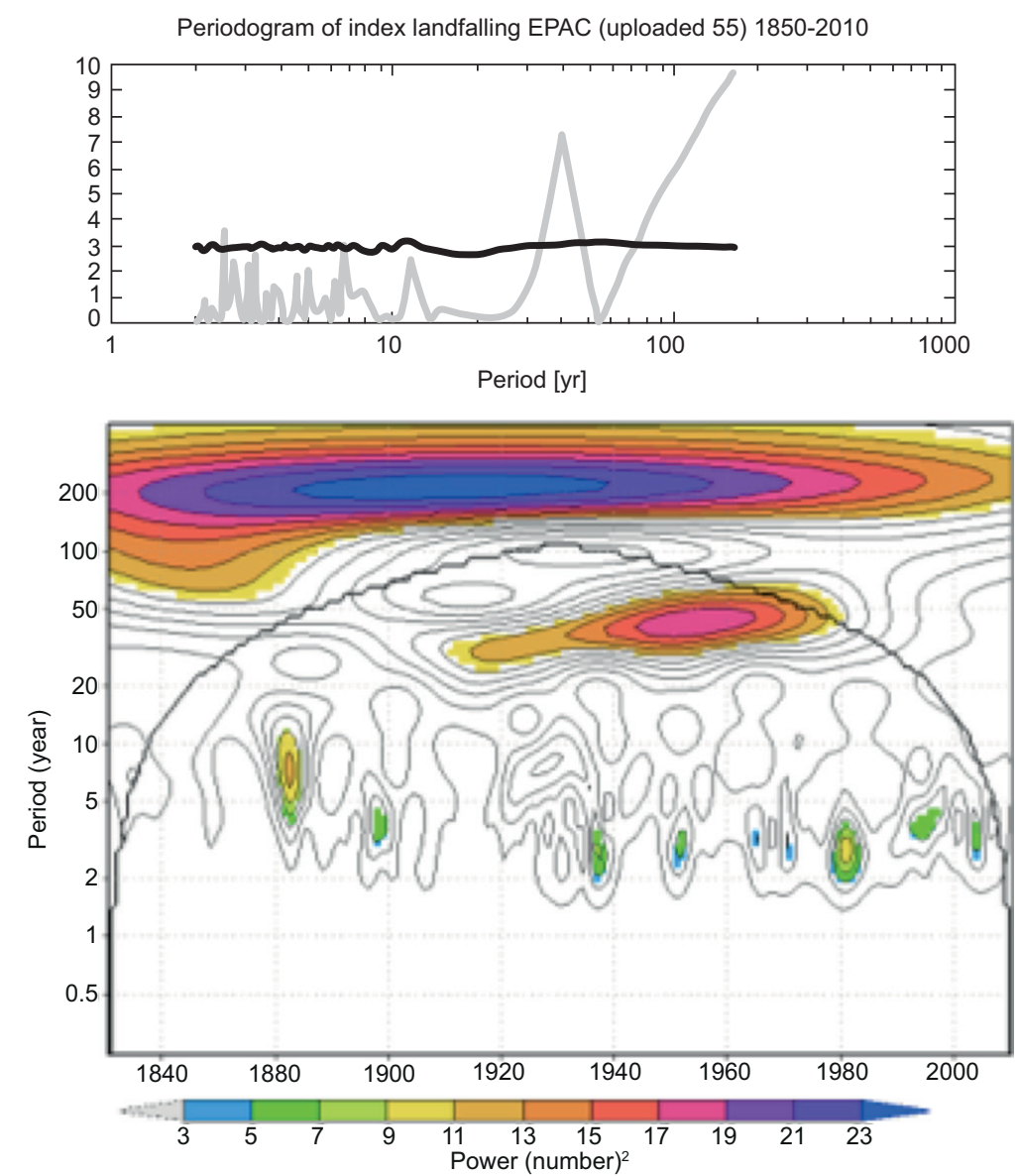

Fig. 6. (a) Periodogram of the time series of the total number of tropical cyclones that made landfall between 1850 and 2010 onto the Pacific Mexican states of Guerrero, Jalisco, Sinaloa and BCS (the black solid line indicates that values below are not significant at the $95 \%$ level). (b) Wavelet analysis of the same time series (the black heavy line indicates the influence cone).

\section{Conclusions}

A time series of landfalling TCs onto the Pacific coast of Mexico was reconstructed, from archived newspapers and historical documents, for a 100-year period: 1850-1949. The study by Serra (1971) reconstructed TCs in the eastern Pacific basin back to 1921 and the NHC database for this basin starts in 1949. Historical documents available only in Mexico have made possible this valuable reconstruction. This study constitutes a major improvement over the currently available information on landfall, extending back the series by another 70 years.

The variability observed in the reconstructed time series is similar to that observed in the NHC database, from 1949 to the present. The analysis of the full time series from 1850 to 2010 results in an annual average of $1.8 \pm 1.6$ landfalls on the west coast of Mexico. No landfalls were observed in $23.6 \%$ of the 161 years analyzed, while years with four or more landfalls occurred in only $16.8 \%$ of the period. A Poisson distribution was fitted to the observed density function and allowed us to estimate that there is a probability of $26.8 \%$ that two landfalls would occur in any given year, while the probability of five landfalls is only $2.7 \%$. 
The analysis to determine the nature of the variability of the landfalling time series indicates that both ENSO and NAO have comparable influences and they are observed throughout the whole 161-year period. A decadal modulation is also observed, particularly strong in the period 1950-1970, but present since the early 20th century. The largest correlation (0.31) is found with the PDO index, at a 99\% confidence level. The suggestion on long-term variability presented by Englehart et al. (2008) in their analysis of the period 1921-2005, is consistent with the variability determined using the dataset from 1850-2010 developed in this study.

Finally, the wealth of social information collected is currently being analyzed and will provide more insight into the full magnitude of the losses due to TC landfalls as well as into the strategies developed by the population to cope with the threat of these recurring natural phenomena.

\section{Acknowledgements}

This work was carried out with the aid of the Inter-American Institute for Global Change Research (IAI, Grant CRN II 2048), which is supported by the U.S. National Science Foundation (Grant GEO-0452325).

\section{References}

Blake E. S., E. J. Gibney, D. P. Brown, M. Mainelli, J. L. Franklin, T. B. Kimberlain and G. R. Hammer, 2009. Tropical cyclones of the eastern North Pacific basin, 1949-2006. Asheville, N.C.: National Climatic Data Center, 162 pp. (Historical Climatology Series 6-5.)

Bradley R. S. and P. D. Jones (eds.), 1992. Climate since A.D. 1500. New York: Routledge, $144 \mathrm{pp}$.

Brito-Castillo L., A. Leyva-Contreras, A. V. Douglas and D. Lluch-Belda, 2002. Pacific Decadal Oscillation and the filled capacity of dams on the rivers of the Gulf of California continental watershed. Atmósfera 15, 121-138.

Camargo S. J., A. W. Robertson, A. G. Barnston and M. Chil, 2008. Clustering of eastern North Pacific tropical cyclones tracks: ENSO and MJO effects. Geochem. Geophys. Geosyst. 9, Q06V05, doi:10.1029/2007GC001861.

Englehart P. J. and A. V. Douglas, 2001. The role of eastern North Pacific tropical storms in the rainfall climatology of western Mexico. Int. J. Climatol. 21, 1357-1370.

Englehart P. J. and A. V. Douglas, 2002. Mexico's summer rainfall patterns: an analysis of regional modes and changes in their teleconnectivity. Atmósfera 15, 147-164.

Englehart P. J., M. D. Lewis and A. V. Douglas, 2008. Defining the frequency of near-shore tropical cyclone activity in the eastern North Pacific from historical surface observations (1921-2005). Geophys. Res. Lett. 35, L03706, doi:10.1029/2007GL032546.

Fernández-Partagás J. and H. F. Diaz, 1996. Atlantic hurricanes in the second half of the nineteenth century. Bull. Amer. Meteorol. Soc. 77, 2899-2906.

García R. R., H. F. Diaz, R. García-Herrera, J. Eischeid, M. R. Prieto, E. Hernández, L. Gimeno, F. Rubio-Durán and A. M. Bascary, 2001. Atmospheric circulation changes in the Tropical Pacific inferred from the voyages of the Manila Galleons in the sixteenth-eighteenth centuries. Bull. Am. Meteorol. Soc. 78, 2435-2455.

García Acosta V., J. M. Pérez Zevallos and A. Molina del Villar, 2003. Desastres agrícolas en México. Catálogo histórico. Mexico: CIESAS/Fondo de Cultura Económica, 506 pp. 
García-Herrera R., R. R. García, M. R. Prieto, E. Hernández, L. Gimeno and H. F. Diaz, 2003. The use of Spanish historical archives to reconstruct climate variability. Bull. Am. Meteorol. Soc. 84, 1025-1035.

Jáuregui E., 2003. Climatology of landfalling hurricanes and tropical storms in México. Atmósfera 16, $193-204$.

Larson J., Y. Zhou and R. W. Higgins, 2005. Characteristics of landfalling tropical cyclones in the United States and Mexico: Climatology and interannual variability. J. Climate 18, 1247-1262.

Padilla-Lozoya R., 2007. El huracán del 59, historia del desastre y reconstrucción de Minatitlán, Colima. Colima, Mexico: Universidad de Colima, 180 pp.

Serra S., 1971. Hurricanes and tropical storms of the w est coast of Mexico. Mon. Wea. Rev. 99, 302-308.

Romero-Vadillo E., O. Zytsev and R. Morales-Pérez, 2007. Tropical cyclone statistics in the northeastern Pacific. Atmósfera 20, 197-213.

Zavala-Sansón L., 2004. The mechanical influence of continental topography on the trajectories of tropical cyclones near the west coast of Mexico. Atmósfera 17, 151-170. 